\title{
Near-shore Fish Populations within St. Pauls Inlet, an Estuarine System in Western Newfoundland
}

\author{
Ryan L. Melanson ${ }^{1}$ and Christine E. Campbel1 ${ }^{1, *}$
}

\begin{abstract}
St. Pauls Inlet, a fjord-type estuary on Newfoundland's west coast, was sampled for near-shore fish populations during August 2010. A total of 1451 fish were caught, comprising 15 species and representing nine families. Sampling was carried out using a 10 -m beach seine, minnow traps, and multi-paneled gill nets. The objective of this study was to document the near-shore fish fauna within St. Pauls Inlet and compare with other data sets from Newfoundland and Labrador. A total of seven sites were sampled along the Inlet and the outer bay. Sites were chosen to best represent a potential range in salinities, and for ease of accessibility. Cluster analysis performed on species presence/absence data indicated high similarity between sites based on the Jaccard similarity coefficient. In terms of regional fish fauna, the St. Pauls sites clustered with freshwater-influenced sites from Bonne Bay (western Newfoundland), and were distinct from the more marine sites of Trinity Bay (eastern Newfoundland) and Gilbert Bay (Labrador).
\end{abstract}

\section{Introduction}

St. Pauls Inlet, located on the west coast of insular Newfoundland, represents a transition zone between temperate and arctic environments and has been designated as a marine area of interest by the Canadian Parks and Wildlife Society (Rao et al. 2009). The Inlet lies at the northern boundary of Gros Morne National Park. An initial study of the physical, chemical, and biological resources of the Inlet was conducted during the summer and fall of 1977 and spring 1978 as part of the process of surveying aquatic ecosystems in the then newly proposed national park. This survey by Carter and MacGregor (1979) suggested moderate near-shore fish diversity, with 23 species identified. No studies of fish populations in the Inlet have been conducted since that time. Based on physical subtidal surveys, dredge samples, and aerial photographs, Carter and MacGregor (1979) found that St. Pauls Inlet contained many subtidal habitats in a small area, potentially leading to a high density of diverse fish communities. In the past (1874 to 1970), the Inlet has supported a lobster and herring fishery (Kudac et al. 2009). By the late 1970s, the herring fishery had collapsed, while the lobster population currently supports only a small fishery of 12 fishers (Kudac et al. 2009). Spawning habitat for herring still exists within the Inlet, which could be essential in reviving a sustainable fishery in the future (Rao et al. 2009).

Information on fish populations within the Inlet could prove useful in efforts to aid in the recovery of stocks and potentially inform community stakeholders. Despite the ecological, economic, and social importance of St. Pauls Inlet to the

${ }^{1}$ Environmental Science, Grenfell Campus, Memorial University of Newfoundland, Corner Brook, NL, Canada A2H 6P9. "Corresponding author - ccampbell@grenfell.mun.ca. 
local region, however, there has been a lack of scientific study conducted in the area within the last 30 years. As such, this study's objective is to assess the fish assemblage currently present within the Inlet and to make regional comparisons with published studies (Currie et al. 2009, Methven et al. 2001, Wroblewski et al. 2007). Comparisons can also be made with Carter and MacGregor (1979) in order to examine possible temporal changes in the fish species composition within St. Pauls Inlet. Assessment of the fish assemblages in an area is crucial to understanding future spatial and temporal variation in response to a shifting environmental conditions such as climate change (Gomes et al. 1995). Assemblages in estuaries are particularly important to understand as estuaries are highly dynamic and often characterized by abrupt environmental changes in temperature, salinity, or oxygen content (Methven et al. 2001, Pritchard 1967).

This project is part of a larger Memorial University of Newfoundland's (MUN) Community-University Research for Recovery Alliance (CURRA) research program that focuses on the importance of fisheries to communities in western Newfoundland (http://www.curra.ca).

\section{Methods}

\section{Field-site description}

St. Pauls Inlet can be considered to be an estuary as defined by Pritchard (1967) because it is a semi-enclosed body of water that has a degree of free connection with the open sea and is measurably diluted with fresh water derived from land drainage. St. Pauls is an example of a fjord-like estuary, as bathometry mapping reveals a steep-walled, U-shaped basin with glacial moraine near the inlet's mouth. The physical environment of coastal western Newfoundland reflects recent glaciations that occurred approximately 12,000 years ago (Rogerson 1983 ) and caused formation of fjord-like valleys. The Inlet is located near the northern limit of Gros Morne National Park (Fig. 1A). The Park envelops a large portion of the land surrounding the fjord-like inlet as well as a significant portion of the waters, but does not encompass the entire inlet. St. Pauls Inlet is $11 \mathrm{~km}$ in length, with width ranging from $6 \mathrm{~km}$ at its widest point in the west and tapering to approximately $1 \mathrm{~km}$ wide at the eastern tail (Carter and MacGregor 1979). The surface area of the inlet is approximately $30 \mathrm{~km}^{2}$. The only brackish water body found within the confines of the Park, St. Pauls Inlet is fed by 24 tributaries (O'Sullivan 1976) and connected to St. Pauls Bay by a restricted opening that is approximately $80 \mathrm{~m}$ wide and $6 \mathrm{~m}$ deep. The largest input of fresh water is Bottom Brook at the eastern end of the inlet (O'Sullivan 1976). The inlet is characterized by shallow depths of 1-3 $\mathrm{m}$ towards the western portion extending into the bay. The eastern portion of the Inlet is steeply sloped, descending to a maximum depth of $36 \mathrm{~m}$ at the center. The coastline within St. Pauls Inlet is composed of substrate formed from glacial scouring, resulting in a variety of steeply sloping rocky beaches as well as shallow and coarse sandy beaches (Carter and MacGregor 1979). The village of St. Paul's is situated between the inlet and the 
more marine St. Pauls Bay. The bay, which opens into the Gulf of St. Lawrence, is characterized by shallow water less than $3 \mathrm{~m}$ deep and sand bars with occasional rocky shores.

Diversity of fish species in St. Pauls Inlet can be compared with diversity data from other areas in Newfoundland and Labrador in order to place St. Pauls in a more regional context. These areas include Bonne Bay (Currie et al. 2009), Gilbert

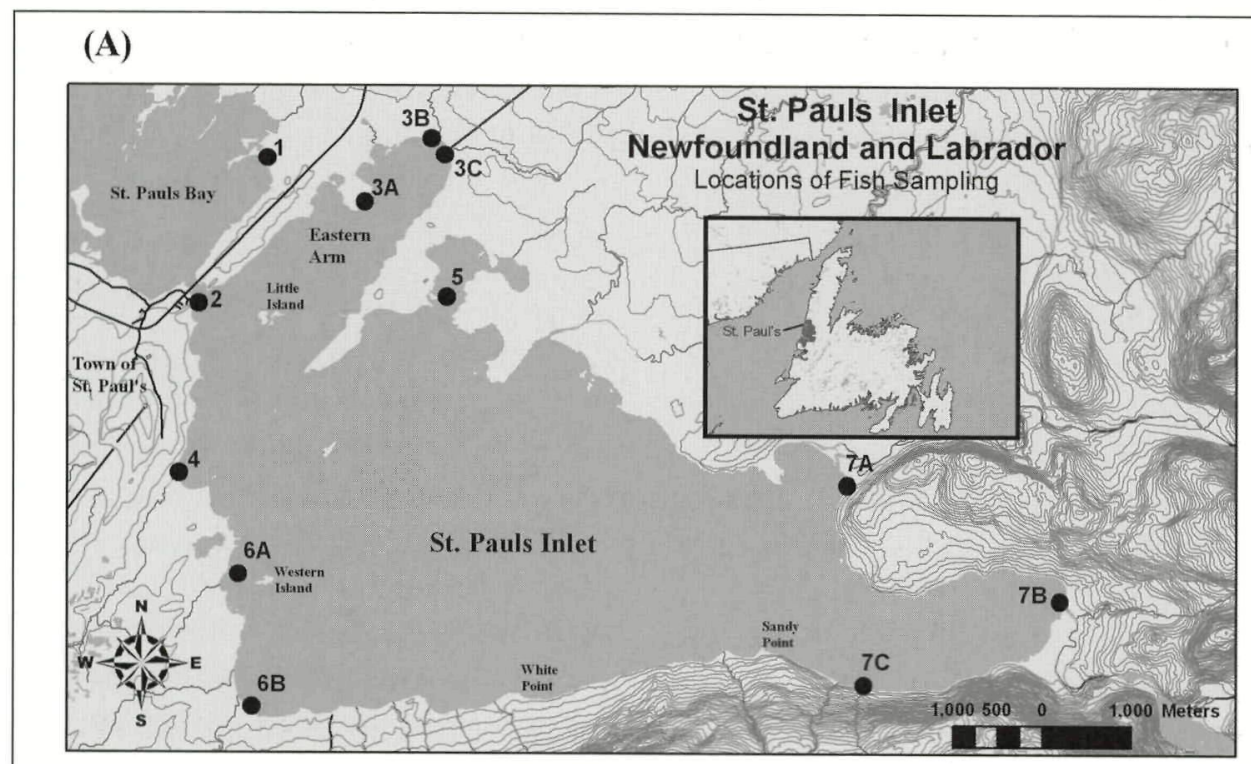

(B)



Figure 1. Map of field sites: (A) The 7 study sites within St. Pauls Inlet; (B) Location of St. Pauls Inlet relative to Bonne Bay, Gilbert Bay, and Trinity Bay, highlighting the location of Gros Morne National Park. Note that St. Pauls Bay opens out directly into the Gulf of St. Lawrence. 
Bay (Wroblewski et al. 2007), and Trinity Bay (Methven et al. 2001). Bonne Bay, a marine fjord system composed of three arms, is located approximately $40 \mathrm{~km}$ south of St. Pauls Inlet, within Gros Morne National Park. This body of water contains an estuarine portion near two large fresh water inputs: Deer Brook and Lomond River. The more northerly Gilbert Bay is a sub-arctic shallow fjord with the characteristics of an estuary. The Gilbert River and Shinneys River flow into this bay, which is located in southeastern Labrador and may contain arctic fish in their southernmost range (Wroblewski et al. 2007). Trinity Bay (Bellevue) is an estuarine environment located on the east coast of Newfoundland. It is flat, protected from waves, and has a substrate of silt accumulating on rock (Methven et al. 2001).

\section{Field sampling}

Sampling took place from 2 August to 28 August 2010. A total of seven sites were sampled: 6 within St. Pauls Inlet and 1 location along St. Pauls Bay (Fig. 1A). Sites were chosen to represent a potential range in salinities and substrate type (Table 1), and for their ease of accessibility. Site 1 was in the more saline bay habitat, closest to the marine environment of the Gulf of St. Lawrence. This region of the Gulf, called the Esquiman Channel, ranges in salinity from 32-36 ppt (Galbraith 2006). Site 2 was selected to examine the transition from the bay into the inlet as defined by the restricted opening and a strong tidal influence. Sites 3-7 were chosen in order to sample over the possible salinity range within the Inlet, ranging from marine conditions near the bay, to a potentially greater freshwater influence nearest the eastern portion at Bottom Brook. Due to logistical constraints (e.g., wind on the inlet was strong and often prohibited travel), sites farthest from the town of St. Paul's were not sampled as frequently as were sites in closer proximity. Supplementary sub-sites were set at some locations to complement the main site and more comprehensively sample the fish fauna.

Table 1. Benthic substrate type, water column salinity, temperature (as measured at $1 \mathrm{~m}$ depth), and gear type used at the 7 sampling sites in St. Pauls Inlet. Gear refers to beach seine (BS), minnow traps (MT) and gill nets (GN). C\&M = Carter and MacGregor (1979).

\begin{tabular}{llccl} 
Site & Substrate type & Mean salinity & Temperature $\left({ }^{\circ} \mathrm{C}\right)$ & Gear \\
\hline 1 & Sand & 21 & 18 & BS, MT \\
2 & Exposed bedrock & 24 & 22 & BS, MT \\
3A & Sand & 21 & 22 & MT \\
$3 \mathrm{~B}$ & Sand & 21 & 22 & MT \\
$3 \mathrm{C}$ & Sand & 20 & 22 & MT \\
4 & Boulders & 24 & 22 & BS, MT \\
5 & Boulders & 13 & 19 & MT \\
$6 \mathrm{~A}$ & Boulders & 21 & 22 & BS \\
$6 \mathrm{~B}$ & Gravel with mud & 22 & 19 & MT \\
$7 \mathrm{~A}$ & Sand & 18 & 21 & BS \\
7B & Sand & 19 & 20 & BS, GN \\
7C & Boulders & 17 & 20 & BS,GN \\
C\&M & Various sites & & & BS, GN \\
\hline
\end{tabular}


Salinity (ppt) and water temperature $\left({ }^{\circ} \mathrm{C}\right)$ were recorded at every sampling location using a YSI model 85 probe.

The main aim of the sampling was to generate qualitative data on the species composition of the near-shore fish fauna. Accordingly, multiple gear types were utilized: $10-\mathrm{m}$ beach seine, minnow traps, and multi-paneled gill nets (Table 1), similar to methods employed by Carter and MacGregor (1979), Currie et al. (2009), Methven et al. (2001), and Wroblewski et al. (2007). Multiple gear types were used since size selectivity can differ substantially between gear types (Methven and Schneider 1998). Not all sites were sampled with the same gear types as the substrates at some locations did not permit their use. The seine was comprised of a $10-\mathrm{m}$ by $1.5-\mathrm{m}$ panel, with $10-\mathrm{mm}$ stretch-mesh netting. The seine was hauled perpendicular to the shoreline by two people wearing chest waders in water no deeper than $1.5 \mathrm{~m}$. A tow length ranging from $10-50 \mathrm{~m}$ was selected based on an initial survey of a site, with catch per unit effort data later standardized per tow length and number of tows. For each sampling date, at least 2 tows were done at each site up to a maximum of 5 tows. Sites 7B and $7 \mathrm{C}$ were sampled on 2 dates with the beach seine, while Sites 1, 2, 4, 6A, and 7A were sampled once. The other sites did not permit the use of the beach seine due to large obstructing boulders. The minnow traps were deployed approximately 5 to $10 \mathrm{~m}$ from shore, fully submerged beneath the water. Each trap was baited with a cup of dry dog food and anchored to the shore by a tether and weight. Traps were standard funnel design, $44 \mathrm{~cm}$ long by $23 \mathrm{~cm}$ wide, with $0.6-$ $\mathrm{cm}$ mesh. Trapping was done on 9 occasions, with traps typically set in the early morning and retrieved in the afternoon. Due to inclement weather on two occasions, traps were left overnight to be retrieved early the next day. Traps were set at $50-150-\mathrm{m}$ intervals along the shoreline, depending on the sampling location, with catch per unit data later standardized per number of traps and total hours set. Gill nets were only used once (due to logistical constraints), on August 15, and only at sites 7B and 7C (having appropriate depths for deployment). The nets were deployed from a small boat and were laid out perpendicular to shore, with the lower end of the net set close to the substrata. Two multi-mesh gill nets were used, one consisting of 9 panels with increasing mesh sizes per panel (19, $24,38,51,64,76,89,101,114 \mathrm{~mm}$ mesh stretch sizes) and the other consisting of 8 panels with the $76-\mathrm{mm}$ mesh stretch panel excluded. Each panel was $15 \mathrm{~m}$ in length and $2.5 \mathrm{~m}$ in height. Total length of the 9-panel net was $135 \mathrm{~m}$; the 8-panel net was $120 \mathrm{~m}$ in length. Each gill net was set for 3 hours, for a total of 6 hours sampling time.

In the previous survey of the inlet, Carter and MacGregor (1979) sampled in the summer and fall of 1977 primarily using gill nets left out overnight (5-panel net, each panel $6 \mathrm{~m}$ long, mesh size from 12 to $88 \mathrm{~mm}$, total of 200 hours operation time) with some daytime beach seining (10-m by $1.3-\mathrm{m}$ seine with $4-\mathrm{mm}$ mesh). They set out gill nets at 9 sites, including Site 7C that was sampled in 2010; beach seining was done at 4 sites corresponding to the 2010 sites of $6 \mathrm{~B}$, $7 \mathrm{~A}, 7 \mathrm{~B}$, and $7 \mathrm{C}$. 
Fish captured during our sampling were removed from the trapping gear and placed into a large pail of inlet water, where they were identified to species and counted. Taxonomic identification was based on Robins et al. (1986) and Scott and Scott (1988). If a fish could not be identified in the field, photographs and detailed morphometric observations were taken to identify the fish ex situ. As soon as the fish were processed, they were returned back to the waters unharmed. Sampling methodology was approved by Memorial University of Newfoundland's Animal Care Committee.

\section{Statistical analysis}

Cluster analysis was used to compare qualitative species composition data between sites within St. Pauls Inlet and 3 other sites in Newfoundland and Labrador (Bonne Bay, Gilbert Bay and Trinity Bay; Fig. 1B). Only beach seine data were used in the cluster analysis, as there were sufficient numbers of sites in the inlet sampled with the seine and similar seine net data were available for other sites in the province (Currie et al. 2009, Methven et al. 2001, Wroblewski et al. 2007). We restricted the cluster comparisons to fish collected using small beach seines (ranging from 9 to $10 \mathrm{~m}$ in length, stretch-mesh size of 9 to $10 \mathrm{~mm}$ ) and with all collections made during the day so as to be most similar to the selectivity of the St. Pauls' gear type. Both Methven et al. (2001) and Wroblewski et al. (2007) observed shifts in species composition between day and night seine collections. There were some differences between the studies in terms of tow lengths and sampling season; however, these should not greatly impact the cluster analysis which was evaluating qualitative data on the presence/absence of species. Use of such qualitative versus quantitative data can reduce the effect of sampling variability when looking at between-site similarity (Omori and Ikeda 1984). The study of Currie et al. (2009) was based on multiple tows undertaken in June over the years 2002-2008. Wroblewski et al. (2007) conducted multiple tows in Gilbert Bay from June to October 2004 and in August 2005, while Methven et al. (2001) conducted standardized tows (length not given) in Trinity Bay over two separate 16-month periods covering 1982-1983 and 1989-1990. While Carter and MacGregor (1979) did use beach seines in addition to gill nets, their report does not clearly outline which fish were caught with which gear, and so their data were not used in the cluster analysis.

Cluster dendrograms were formed with Jaccard's coefficient of similarity, which is based on the presence and absence of species in pairwise comparison of sites (Omori and Ikeda 1984). Such analysis assigns each site to a group and then clusters the groups (so that sites with similar species composition are clustered together) to aid in identifying biogeographic patterns in species assemblages (Jackson et al. 1989). Unweighted pair-group method using arithmetic averages (UPGMA) was the agglomerative hierarchical method utilized in the cluster analysis. All similarity matrices and cluster analyses were carried out using the Numerical Taxonomy and Multivariate Analysis System (NTSYSpc) version 2.21L (Rohlf 2009). 


\section{Results}

A total of 1451 fish were collected from St. Pauls Inlet in August 2010 using all sampling gears, comprising 15 species and representing nine families (Tables 2, 3). Six species of fish accounted for $98 \%$ of the total fish sampled: Pungitius pungitius (Ninespine Stickleback) 60\%, Gasterosteus aculeatus (Threespine Stickleback) 18\%, Gasterosteus wheatlandi (Blackspotted Stickleback) 7\%,

Table 2. Fish species collected from St. Pauls Inlet in 2010 compared with collections from 1977 by Carter and MacGregor (1979).

\begin{tabular}{|c|c|c|c|}
\hline Species & Common name & 2010 & 1977 \\
\hline \multicolumn{4}{|l|}{ Anguillidae } \\
\hline Anguilla rostrata (Lesueur) & American Eel & $\mathrm{X}$ & $\mathrm{X}$ \\
\hline \multicolumn{4}{|l|}{ Clupeidae } \\
\hline Clupea harengus L. & Atlantic Herring & & $\mathrm{X}$ \\
\hline \multicolumn{4}{|l|}{ Salmonidae } \\
\hline Salvelinus fontinalis Mitchill & Brook Trout & $\mathrm{X}$ & $\mathrm{X}$ \\
\hline \multicolumn{4}{|l|}{ Osmeridae } \\
\hline Osmerus mordax Mitchill & American Smelt & $\mathrm{X}$ & $\mathrm{X}$ \\
\hline \multicolumn{4}{|l|}{ Gadidae } \\
\hline Gadus morhua (L.) & Atlantic Cod & & $\mathrm{X}$ \\
\hline Microgadus tomcod (Walbaum) & Atlantic Tomcod & $X$ & $\mathrm{X}$ \\
\hline Urophycis tenuis (Mitchill) & White Hake & $X$ & \\
\hline \multicolumn{4}{|l|}{ Gasterosteidae } \\
\hline Apeltes quadracus (Mitchill) & Fourspine Stickleback & $\mathrm{X}$ & \\
\hline Gasterosteus aculeatus (L.) & Threespine Stickleback & $X$ & $\mathrm{X}$ \\
\hline Gasterosteus wheatlandi (Putnam) & Blackspotted Stickleback & $X$ & \\
\hline Pungitius pungitius (L.) & Ninespine Stickleback & $\mathrm{X}$ & $\mathrm{X}$ \\
\hline \multicolumn{4}{|l|}{ Labridae } \\
\hline Tautogolabrus adspersus (Walbaum) & Cunner & $\mathrm{X}$ & $\mathrm{X}$ \\
\hline \multicolumn{4}{|l|}{ Zoarcidae } \\
\hline Zoarces americanus (Bloch \& Schneider) & Ocean Pout & & $\mathrm{X}$ \\
\hline \multicolumn{4}{|l|}{ Stichaeidae } \\
\hline Lumpenus maculates (Fries) & Daubed Shanny & & $\mathrm{X}$ \\
\hline Ulvaria subbifurcata (Storer) & Radiated Shanny & & $\mathrm{X}$ \\
\hline Stichaeus punctatus (Fabricus) & Arctic Shanny & & $\mathrm{X}$ \\
\hline \multicolumn{4}{|l|}{ Pholidae } \\
\hline Pholis gunnellus (L.) & Rock Gunnel & $\mathrm{X}$ & $\mathrm{X}$ \\
\hline \multicolumn{4}{|l|}{ Ammodytidae } \\
\hline Ammodytes americanus DeKay & American Sand Lance & & $\mathrm{X}$ \\
\hline \multicolumn{4}{|l|}{ Scombridae } \\
\hline Scomber scombrus L. & Atlantic Mackerel & & $\mathrm{X}$ \\
\hline \multicolumn{4}{|l|}{ Cottidae } \\
\hline Myoxocephalus aeneus (Mitchill) & Grubby & $\mathrm{X}$ & $\mathrm{X}$ \\
\hline Myoxocephalus octodecemspinous (Mitchill) & Longhorn Sculpin & $\mathrm{X}$ & $\hat{X}$ \\
\hline Myoxocephalus scorpius (L.) & Shorthorn Sculpin & $\hat{X}$ & $\hat{x}$ \\
\hline Triglops murrayi Günther & Moustache Sculpin & & $\mathrm{X}$ \\
\hline \multicolumn{4}{|l|}{ Cyclopteridae } \\
\hline Cyclopterus lumpus L. & Lumpfish & & $\mathrm{X}$ \\
\hline \multicolumn{4}{|l|}{ Pleuronectidae } \\
\hline Limanda ferruginea (Storer) & Yellowtail Flounder & & $\mathrm{X}$ \\
\hline Pseudopleuronectes americanus (Walbaum) & Winter Flounder & $\mathrm{X}$ & $\mathrm{X}$ \\
\hline
\end{tabular}




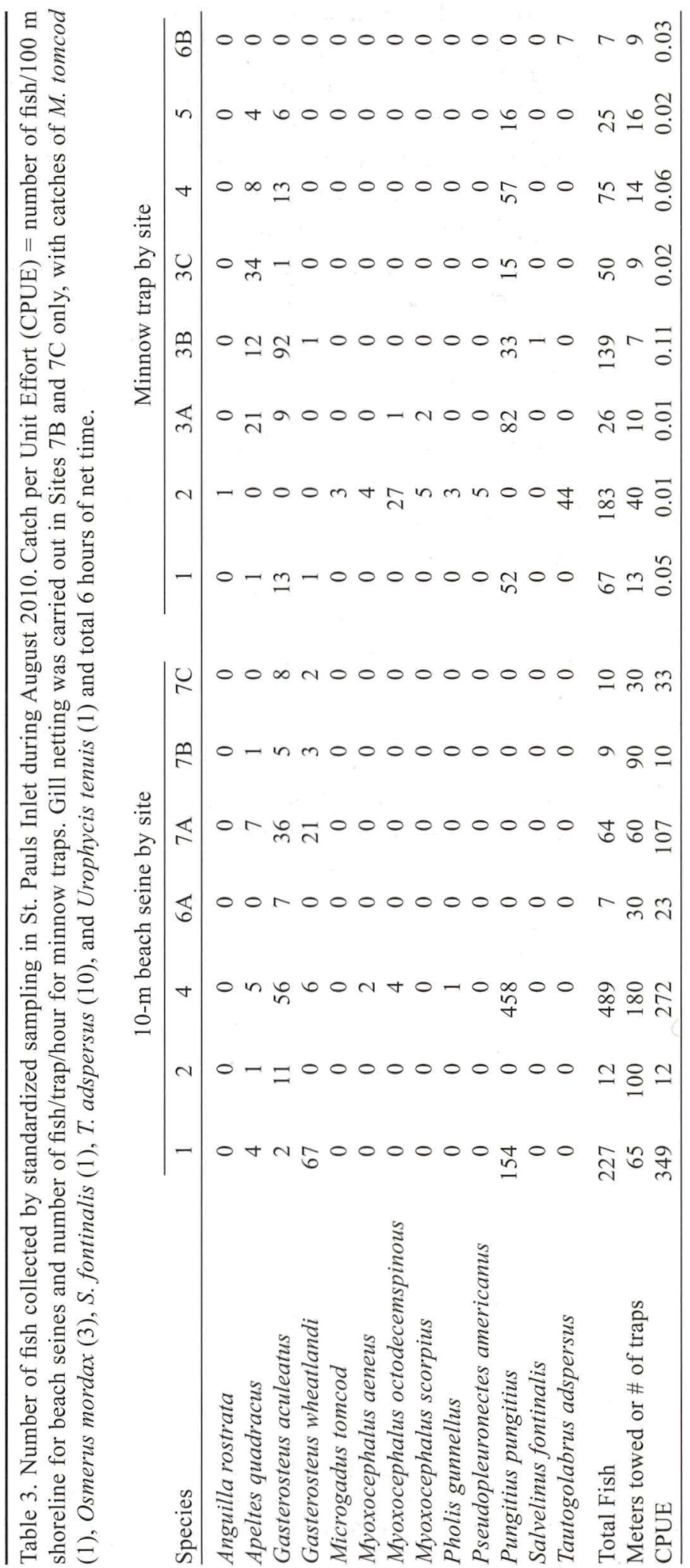


Apeltes quadracus (Fourspine Stickleback) 7\%, Tautogolabrus adspersus (Cunner) 4\%, and Myoxocephalus octodecemspinosus (Longhorn Sculpin) 2\%. The most commonly collected species was Threespine Stickleback, found at all 15 sampling sites. Together the four stickleback species accounted for $99 \%$ of fish captured in the beach seines. The most infrequently collected species were $A n$ guilla rostrata (American Eel) and Urophycis tenuis (White Hake), both caught just once during sampling, the former in a minnow trap and the latter in a gill net. Highest species richness was observed at Site 2 and Site 4, with ten species and seven species, respectively (corresponding site salinities of 24 and 13 ppt). Lowest species richness was observed at Site 6A and Site 6B (corresponding salinities of 21 and $22 \mathrm{ppt}$ ), with only Threespine Stickleback found at 6A and Cunner at 6B (Table 3). Average salinity concentrations at the different sites along the inlet ranged from $13 \mathrm{ppt}$ at Site 5 to $24 \mathrm{ppt}$ at Site 4 (see Table 1).

Cluster analysis performed on the $10-\mathrm{m}$ beach seine data using Jaccard's coefficient showed no distinct clusters of species within the inlet (Fig. 2). All sites exhibited similar species composition, with initial separation at about $40 \%$ similarity. Overall catches ranged from 10 to 349 fish/100 m towed by beach seines in Sites 7B and 1, respectively, and from 0.01 to 0.11 fish/trap/hour for the minnow traps in Sites 2, 3A, and 3B, respectively (Table 3).

\section{St. Pauls comparisons}

Species list comparisons between the present study and Carter and MacGregor's (1979) study revealed some differences in fish fauna sampled in the Inlet (Table 2). A total of 23 species had been previously captured by Carter and MacGregor (1979). Eleven of the 23 species collected in 1979 were not captured in 2010. These include Clupea harengus (Atlantic Herring), Gadus morhua

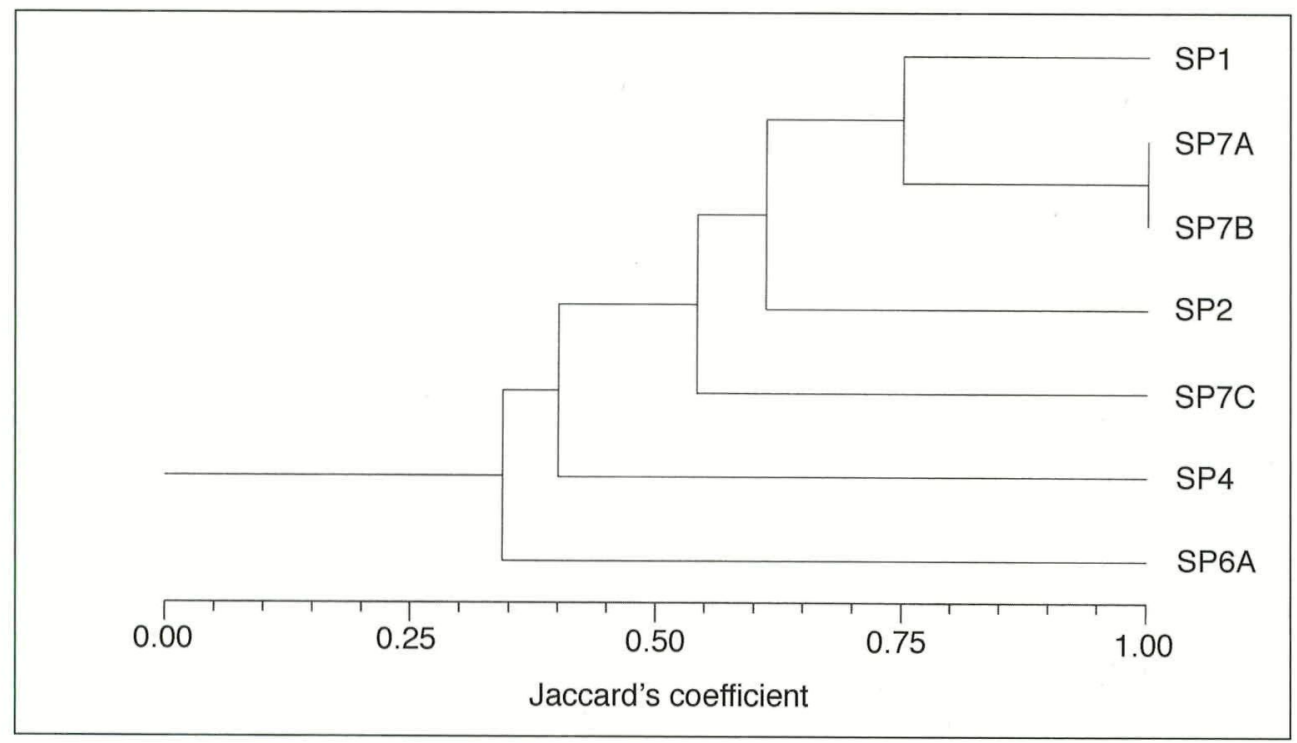

Figure 2. Cluster dendrogram for 10-m beach seine data during August 2010 sampling in St. Pauls Inlet. 
(Atlantic Cod), Zoarces americanus (Ocean Pout), Lumpenus maculates (Daubed Shanny), Ulvaria subbifurcata (Radiated Shanny), Stichaeus punctatus (Arctic Shanny), Ammodytes americanus (American Sand Lance), Scomber scombrus (Atlantic Mackerel), Triglops murrayi (Moustache Sculpin), Cyclopterus lumpus (Lumpfish), and Limanda ferruginea (Yellowtail Flounder). Three species recorded in 2010 were not recorded in 1979: Fourspine Stickleback, Blackspotted Stickleback, and White Hake. Identification of Ninespine Stickleback in 1979 was based on a diver's observation of a single specimen; the current study found this species to be the most abundant fish collected, primarily found in Site 1 and Site 4 beach seines, as well as being common in minnow traps at most sites.

Regional comparisons of the beach seine data using cluster analysis showed St. Pauls Inlet to be somewhat distinct in terms of species composition (Fig. 3). Three clusters separated out at $19 \%$, indicating clear separation between locations. The first cluster grouping contained all the St. Pauls sites as well as Bonne Bay sites 3A (Deer Arm barachois) and 4A(Lomond River delta). The second cluster group contained most of the other Bonne Bay sites together with the Trinity Bay and Gilbert Bay sites. The Gilbert Bay sites grouped together in a sub-cluster. Bonne Bay Site 4 separated out from the other sites in a third cluster.

\section{Discussion}

Comparison of our data set with that of Carter and MacGregor (1979) suggests possible shifts in species abundance and composition of the near-shore fish fauna. Fifteen fish species were collected in St. Pauls Inlet in 2010, contrasting with the

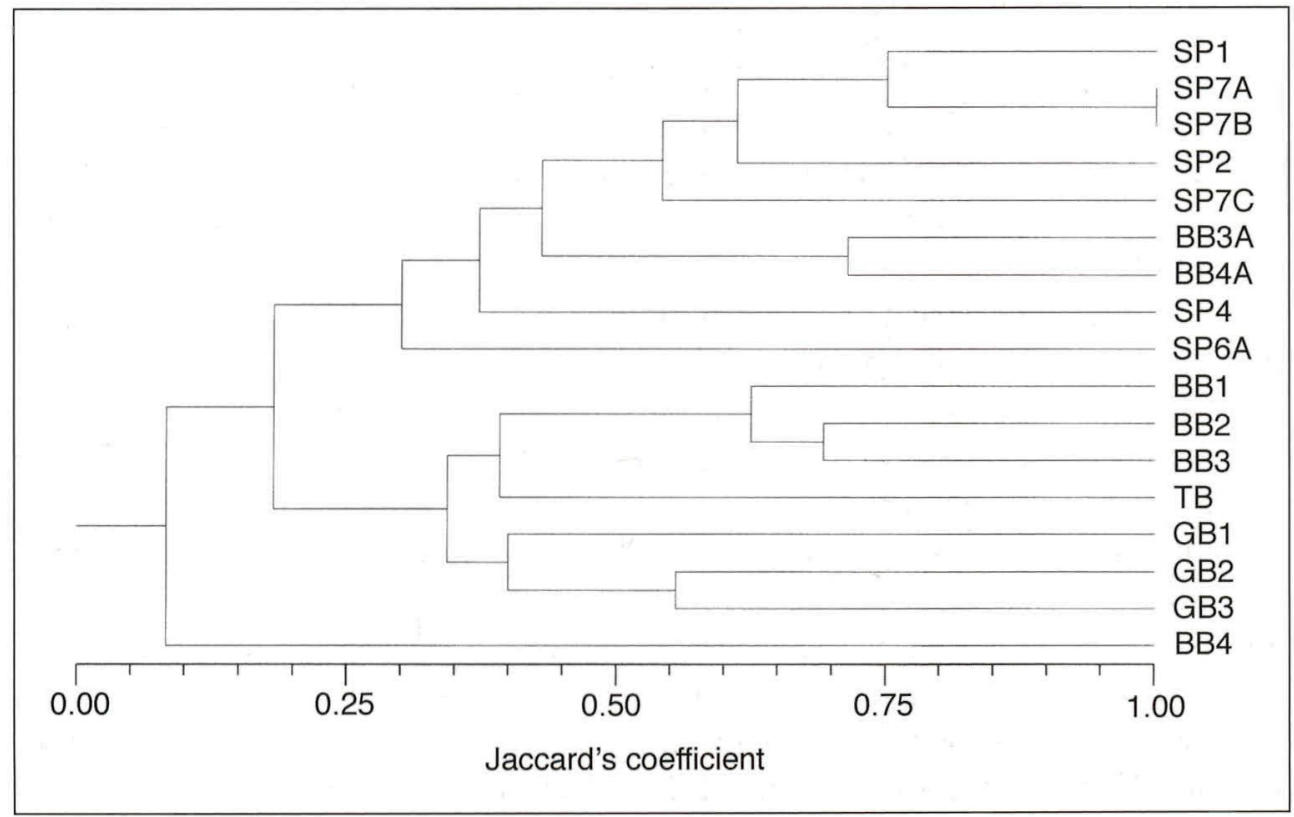

Figure 3. Cluster dendrogram for $10-\mathrm{m}$ beach seine data comparing St. Pauls data (SP) with Bonne Bay (BB; Currie et al. 2009), Gilbert Bay (GB; Wroblewski et al. 2007) and Trinity Bay (TB; Methven et al. 2001). 
23 species collected in 1977 by Carter and MacGregor. Differences in sampling methodology that exist between the two studies, however, mean that any explanations for changes in species composition (e.g., long-term climate change) must be treated with caution.

Site selection and timing of sampling were similar in both studies. Sampling in 2010 took place during August, while fish were sampled during July and August and in late September in 1977. However, intensity of gear use was not the same. The present study used minnow traps, in addition to beach seine and gill nets, whereas Carter and MacGregor (1979) used only beach seine and gill nets. More importantly, Carter and MacGregor (1979) logged approximately 200 hours of gill netting at 9 sites over the inlet, whereas we logged only a total of 6 hours of gill netting at 2 sites (7B and 7C). Gill netting is important for sampling pelagic fish species (i.e., species that were not collected in 2010 but were collected in 1977). One species that was caught in the 2010 gill netting but not in the 1977 gill netting was White Hake. Threespine Stickleback was found to be abundant in both studies. However, collection of the other stickleback species only in 2010 would seem to reflect the present study's increase in shallow-water sampling by minnow traps and beach seines. In particular, sticklebacks were common in the minnow traps set out in Sites 3A, 3B, and 3C, all from the inlet's Eastern Arm, a shallow region not sampled by Carter and MacGregor (1979). Ninespine Stickleback also seemed to be concentrated most strongly at Sites 1 and 4 (based on the beach seine data; Table 3); neither of these sites were sampled by Carter and MacGregor (1979), which could suggest why they observed this species to be rare.

Based on both data sets, a total of 26 species have now been identified from St. Pauls Inlet (Table 2). Species composition did not markedly differ between sites within the Inlet, as based on cluster analysis of the seine data. Threespine Stickleback was found at all sites and was the only species collected from Site 6A. Ninespine Stickleback was collected in the highest numbers (total of 867 fish).

Observed species richness of fish fauna in St. Pauls Inlet is within the range of values from other estuarine systems in Newfoundland and Labrador. Studies from Bonne Bay have documented a total of 32 fish species (Currie et al. 2009). Wroblewski et al. (2007) list 25 species from Gilbert Bay in Labrador, with 3 of the species (Acipenser oxyrinchus oxyrinchus Mitchill [Atlantic Sturgeon], Asidophoroides monoterygius (Bloch) [Alligatorfish], and Atlantic Mackerel) collected by non-standard gill netting ( $91.5 \mathrm{~m}$ by $2.4 \mathrm{~m}$; 14-cm stretch mesh) and one species (Moustache Sculpin) collected by hook and line. Methven et al. (2001) identified 23 species from Bellevue, Trinity Bay, with Threespine Stickleback, Blackspotted Stickleback, American Smelt, and cod species (both Atlantic Cod and Gadus ogac Richardson [Greenland Cod]) predominant. Low species richness is typical of north-temperate estuarine fish fauna (Haedrich 1983). Furey and Sulikowski (2011) noted that beach seine collections from estuaries in Maine yielded 24 to 27 fish species. Fundulus species, often collected 
from north-temperate estuaries (e.g., Furey and Sulikowski 2011, Scott and Scott 1988) were not found in St. Pauls Inlet; this result corresponds with work by Knight (2002), who sampled coastal lowland areas in Gros Morne National Park extensively for Fundulus diaphanus diaphanus (Newfoundland population of the Eastern Banded Killifish) and found no Fundulus species.

The larger regional comparison also indicates distinct spatial clusters. The St. Pauls sites clustered together with the two Bonne Bay sites (BB3A and BB4A) that were most influenced by freshwater input. These two Bonne Bay sites are associated with the two main freshwater sources draining into Bonne Bay: Deer Brook for Site BB3A and Lomond River for Site BB4A. Both Site BB3A and Site BB4A are strongly estuarine according to Currie et al. (2009). Sites from Gilbert Bay and Bellevue clustered together with the more marine Bonne Bay sites. Bonne Bay Sites 1-3 were highly influenced by the ocean (Currie et al. 2009). Salinity recorded from both Gilbert Bay (27-32 ppt) and Bellevue (23-31 ppt) illustrate the marine nature of these sites. Site BB4 (Lomond Cove) is brackish, with only three species collected (Salmo salar [Atlantic Salmon], Salvelinus fontinalis [Brook Trout], and Pseudopleuronectes americanus [Winter Flounder]). The low number of species might explain why this site did not group together with the other Bonne Bay sites.

One of the most important factors determining species abundance and composition in estuaries can be seasonal variation in fish assemblages (Methven et al. 2001). The current St. Pauls study took place during one month (August). Therefore, it is possible that some species may not have been captured in the inlet because they were not present during the sampling period. However, based on results from other studies, August sampling should provide the best opportunity to describe the majority of fish species present in St. Pauls Inlet. Methven et al. (2001) found that species richness in Trinity Bay was highest in August and September and lowest in January and February, and the number of individual fish caught was highest from July to October and lowest in the coldest months of December to March. Wroblewski et al. (2007) also found species richness to be highest in August, with sampling conducted over the open water period from June to October in Gilbert Bay.

The fish fauna of St. Pauls inlet can be classified as estuarine and relatively depauperate, and as such, the Inlet may be representative of other restricted fjords located on the west coast of Newfoundland, such as Parsons Pond and Portland Creek Pond, both north of St. Pauls. Within the inlet, there were no obvious patterns in species composition that could be related to salinity gradients. Unlike the more productive Bonne Bay, from which both Atlantic Herring and Atlantic Cod have been collected (Currie et al. 2009), the contribution of St. Pauls Inlet to commercial fish stocks is not clear. No specimens of Atlantic Herring or Atlantic Cod were found in the Inlet during the 2010 study, although both species were noted in the 1979 study with its more intensive gill netting. Future gill netting in the inlet will allow for more definite conclusions to be drawn as to any temporal changes in the near-shore fish fauna, as well as allow for an evaluation of the 
contribution of the inlet to the overall biological productivity of the larger west coast marine ecosystem.

\section{Acknowledgments}

Dr. Tom Knight from Parks Canada provided invaluable suggestions during the sampling process. As well, Mr. Willis Payne, a St. Paul's resident and boat captain, provided crucial transportation across St. Pauls Inlet. Special thanks to Megan Carter, Ryan MacDonald, Erin Stevens, and Hershey for help collecting data. Funding to Ryan Melanson was provided through the Gros Morne National Park University Environmental Internship.

\section{Literature Cited}

Carter, J.A., and C.D. MacGregor. 1979. Marine Inventory of St. Pauls Inlet for Gros Morne National Park. Report for Parks Canada by Martec Limited, Halifax, NS.

Currie, J.J., J.S. Wroblewski, D.A. Methven, and R.G. Hooper. 2009. Near shore fish fauna of Bonne Bay, a fjord within Gros Morne National Park, Newfoundland. Community-University Research for Recovery Alliance (CURRA). Memorial University of Newfoundland. Available online at http://www.curra.ca/documents/Currie $\% 20$ et\%20al\%20CURRA\%20Report\%20Sept09.pdf. Accessed 1 November 2010.

Furey, N.B., and J.A. Sulikowski. 2011. The fish assemblage structure of the Saco River estuary. Northeastern Naturalist 18:37-44.

Galbraith, P.S. 2006. Winter water masses in the Gulf of St. Lawrence. Journal of Geophysical Research 111:1-23.

Gomes, M.C., R.L. Haedrich, and M.G. Villagarcia. 1995. Spatial and temporal changes in the groundfish assemblages on the northeast Newfoundland Labrador Shelf, northwest Atlantic, 1978-1991. Fisheries Oceanography 4:85-101.

Haedrich, R.L. 1983. Estuarine fishes. Pp. 183-207, In B.H. Kethchum (Ed.). Estuaries and Enclosed Seas. Ecosystems of the World 26. Elsevier Scientific, New York, NY.

Jackson, D.A., K.M. Somers, and H.H. Harvey. 1989. Similarity coefficients: Measures of co-occurrences and association or simply measures of occurrence? American Naturalist 133:436-453.

Knight, T.W. 2002. The distribution and status of the Eastern Banded Killifish, Fundulus diaphanus, in Gros Morne National Park of Canada, Newfoundland. Parks Canada Species at Risk Recovery Fund, 2000-2001. SARRF-21. Rocky Harbour, NL, Canada.

Kudac, J., K. Korneski, and R. Chuenpagdee. 2009. St. Pauls: Past, present, future. Memorial University of Newfoundland, St. John's, NL, Canada.

Methven, D.A., and D.C. Schneider. 1998. Gear-independent patterns of variation in catch of juvenile Atlantic Cod (Gadus morhua) in coastal habitats. Canadian Journal of Fisheries and Aquatic Sciences 55:1430-1442.

Methven, D.A., R.L. Haedrich, and G.A. Rose. 2001. The fish assemblage of a Newfoundland estuary: Diel, monthly, and annual variation. Estuarine, Coastal, and Shelf Science 52:669-687.

Omori, M., and T. Ikeda. 1984. Methods in Marine Zooplankton Ecology. Wiley-Interscience, John Wiley and Sons, New York, NY. 332 pp.

O'Sullivan, W. 1976. Hydrological inventory of Gros Morne National Park, Newfoundland, Canada. Inland Waters Directorate, Water Resources Branch, Halifax, NS, Canada. 
Pritchard, D.W. 1967. What is an estuary: Physical viewpoint? American Association for the Advancement of Science 85:37.

Rao, A., L. Outhouse, and D. Gregory. 2009. Special marine areas in Newfoundland and Labrador. Canadian Parks and Wilderness Society - Newfoundland and Labrador Chapter, St. John's, NL, Canada.

Robins, C.R., G.C. Ray, and J. Douglass. 1986. A Field Guide to Atlantic Coast Fishes of North America. Houghton Mifflin Company, Boston, MA.

Rogerson, R.J. 1983. Geological evolution. Pp. 5-36, In G.R. Robin (Ed.). Biogeography and Ecology of the Island of Newfoundland. Dr. W. Junk Publishers, The Hague, Netherlands.

Rohlf, F.J. 2009. NTSYSpc Numerical taxonomy and multivariate analysis system version 2.21L. Exeter Software. Setauket, NY.

Scott, W.B., and M.G. Scott. 1988. Atlantic fishes of Canada. Canadian Bulletin of Fisheries and Aquatic Sciences 219:1-731.

Wroblewski, J.S., L.K. Kryger-Hann, D.A. Methven, and R.L. Haedrich. 2007. The fish fauna of Gilbert Bay, Labrador: A marine protected area in the Canadian subarctic coastal zone. Journal of the Marine Biological Association of the United Kingdom 87:575-587. 
Copyright of Northeastern Naturalist is the property of Humboldt Field Research Institute and its content may not be copied or emailed to multiple sites or posted to a listserv without the copyright holder's express written permission. However, users may print, download, or email articles for individual use. 